University of Pennsylvania Carey Law School

Penn Carey Law: Legal Scholarship Repository

Faculty Scholarship at Penn Carey Law

$1-1-2012$

\title{
Mobile Phones and Crime Deterrence: An Underappreciated Link
}

Jonathan Klick

University of Pennsylvania Carey Law School

John MacDonald

University of Pennsylvania

Thomas Stratmann

George Mason University

Follow this and additional works at: https://scholarship.law.upenn.edu/faculty_scholarship

Part of the Behavioral Economics Commons, Criminal Law Commons, Criminology Commons, Law and Economics Commons, Law and Society Commons, and the Science and Technology Law Commons

\section{Repository Citation}

Klick, Jonathan; MacDonald, John; and Stratmann, Thomas, "Mobile Phones and Crime Deterrence: An Underappreciated Link" (2012). Faculty Scholarship at Penn Carey Law. 426.

https://scholarship.law.upenn.edu/faculty_scholarship/426

This Book Chapter is brought to you for free and open access by Penn Carey Law: Legal Scholarship Repository. It has been accepted for inclusion in Faculty Scholarship at Penn Carey Law by an authorized administrator of Penn Carey Law: Legal Scholarship Repository. For more information, please contact PennlawIR@law.upenn.edu. 
Mobile Phones and Crime Deterrence: An Underappreciated Link

Jonathan Klick

John MacDonald

Thomas Stratmann

Introduction

The crime decline observed in the 1990s is remarkable. Between 1991 and 2001, crime rates dropped by about a third across all crime categories. Perhaps more notable, this decline was almost completely unforeseen. Given the sheer magnitude of this unpredicted decline, it is not surprising that finding explanations for it is a central focus of modern empirical crime scholarship.

Explanations range from the intuitive, more cops equal less crime (e.g., Evans and Owens 2007) as does the greater use of prison (Spelman 2006), to the provocative, legalized abortion culls the population of potential criminals (Donohue and Levitt 2001), and everything in between. In an influential review of the topic, Levitt (2004) suggests that four factors, abortion legalization, increases in police forces, changes in the market for crack cocaine, and rising prison populations, account for virtually all the crime decline. Of these factors, Levitt and other scholars suggest prisons provide the largest contribution to the crime drop (Blumstein and Wallman 2000).

However, Levitt notes a puzzle. Prison populations increased during the period 1973-1991. Based on the calculations he uses to analyze the 1991-2001 period, he would have predicted large crime rate declines in the earlier period too when, in fact, reported crime increased significantly in the 1970s and 80s according to the FBI's Uniform Crime Report (UCR) data. To some extent, concerns about reported property crime are mitigated when alternate self report data are used. Crime rates documented using the National Crime Victimization Survey (NCVS) data show that property crime rates appear to decline by the magnitude Levitt predicts. The NCVS data do not support Levitt's violent crime estimates. This leads Levitt to suggest that there was something different occurring in the earlier period, rather than leading him to revise the confidence he has in his 1991-2001 analysis. ${ }^{1}$

Cook and Laub (2002) also note that these cohort and period explanations for the crime decline in the 1990s do not account for the fact that the sharpest drop in violent crime rates occurred among older adults. Rising violence rates among young adults from the 1980s and 1990s have remained fairly stable in the post-crime drop period, suggesting that shifting cohorts from legalized abortion aren't likely the cause of the crime drop. Cook and MacDonald (2010) also

\footnotetext{
${ }^{1}$ The sampling frame for the NCVS under counts homeless and criminal offenders currently serving time in jail or prisons. This subpopulation of individuals are the most likely to be victims of violent crime.
} 
note that sharp period effects are less evident for property crimes, where the data from NCVS suggest that property crime rates began dropping in significantly in the late 1970s. Residential burglaries (break-ins and attempts) in particular have declined by 70\% between 1976 and 2007.

While it is reasonable to suggest that effects may change over time, thus explaining the discrepancy in fit of explanations between periods, another approach is to look for unaccounted for factors that may bias the estimates used for these calculations, focusing especially on factors that might have been at work in the later period of the 1990s but not during the earlier decades. Some possibilities include the effect of declining lead exposure levels for children in the 1970s and 80s as discussed in Reyes (2007) and changes in fetal alcohol exposure occurring after this was identified as a harm to children in the medical literature in 1973. The desegregation of schools in states through court orders to enforce Brown v. Board of Education is another example (Weiner, Lutz, and Ludwig 2010). The growth in private security in public spaces through the expansion of business improvement districts in the 1990s also appears to be associated with significant reductions in crime in a few case studies (Brooks 2008; Cook and MacDonald 2011a).

The expansion of new crime prevention technologies is another set of factors that might be at work during the crime drop of the 1990s. Technologies for motor vehicle theft prevention including the installation of immobilizers and vehicle-tracking systems like Lojack (Ayres and Levitt 1998) and OnStar appear to be associated with dramatic reductions in theft rates in the United Kingdom and the United States (Cook and MacDonald, 2011b).

Along those lines, in this chapter, we present a novel suggestion that the introduction and growth of mobile phone technology may have contributed to the crime decline in the 1990s, specifically in the areas of rape and assault. While mobile phone data availability precludes us from directly investigating this link, examination of later data suggests that such a link is plausible and could be an important missing element in understanding what happened in the 1990s. Given that mobile phones increase surveillance and the risks of apprehension when committing crimes against strangers, an expansion of this technology would increase the costs of crime as perceived by forward-looking criminals.

Although official sources do not document mobile phone subscriptions before 1999, general impressions do match up with many of the stylized facts concerning the crime decline in the 90s. The first commercially available mobile phone was introduced in 1983, but it wasn't until the mid 1990s that more than a trivial share of the US population used the technology as seen in Figure 1. This coincides with the beginning of the crime decline. 


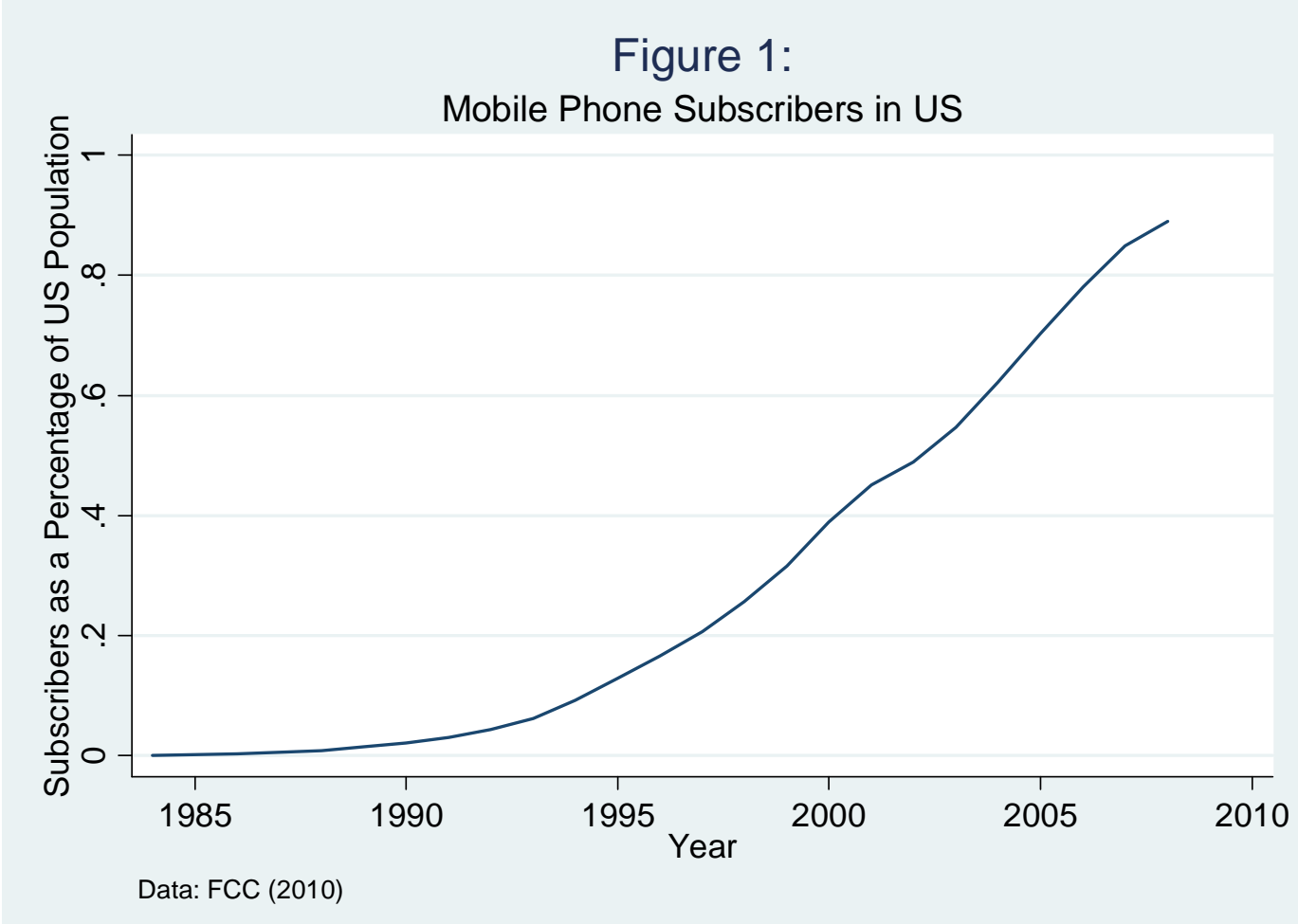

Other facts about the crime decline highlighted by Levitt (2004) such as the concentration of the effect in urban areas and the fact that the decline was greatest in the Northeast appear to match the stylized facts regarding the growth of the mobile phone market as well.

In this chapter, we present the intuition behind a connection between mobile phones and crime. We then use the available mobile phone data to show that there is a strongly negative association between mobile phones and violent crimes, although data limitations preclude us from being able to make any claims about causality. We show how the intuition about mobile phones providing crime deterrence fits in nicely with modern discussions in the crime literature regarding optimal policy and the expanding use of private security precautions in crime prevention.

\section{Mobile Phones and Crime}

In the standard Becker framework, an individual commits a crime if the expected benefits of the crime exceed the costs. The expected benefits include any pecuniary or psychic benefits the individual receives from the crime. These benefits are adjusted by the individual's perceived likelihood of success. The expected cost side of the inequality includes the likelihood the individual will be punished and the individual's utility loss from the punishment.

The likelihood of punishment includes a number of factors, including the likelihood the individual will be identified, apprehended, prosecuted, convicted, and punished as well as extra- 
legal factors such as the likelihood the victim or bystanders will mete out punishments defensively or as vigilantes. Most public policy interventions focus on this side of the equation, attempting to increase either the likelihood of punishment or the utility loss arising from the punishment.

Cook (1986) notes that opportunities for crime vary substantially by the attractiveness of potential victims and their level of investment in their own protection. A routine activities theory of crime is also consistent with a Becker framework (Cohen and Felson 1979). Routine activities theory suggests that crime on the aggregate increases with an increasing convergence between suitable targets of crime, potential offenders, and the lack of capable guardians against a violation. Mobile phones provide additional surveillance of motivated offenders which is a form of increased guardianship for suitable targets of crime.

The presence of mobile phones increases the likelihood of punishment along a number of different margins. Unless law enforcement personnel happen to be located in close proximity to a crime, the first step toward punishment involves reporting the crime. Historically, for crimes committed between strangers, this involved seeking out a police officer or finding an available residential or pay phone from which the police could be called. These costs, no doubt, discouraged the reporting of some crimes, and, at a minimum, introduced delay in the reporting process. Further, this delay likely led to the loss of some details about the crime and the individual committing it which, in turn, lowered the likelihood of identification and apprehension. Data from the 1980s in the U.S. indicates that the police made an immediate arrest in less than 3\% of serious crime calls for service (Sherman, 1995). Delayed reporting and the attendant information loss might increase sources of doubt, leading to more difficulty in building an effective prosecution and reducing the chances of convictions.

Mobile phones, however, allow for quicker reporting of crimes and, in some cases, real time communication of details about the crime and the criminal. In an environment where phones are ubiquitous, the cost of reporting approaches zero, negating all the problems of delay discussed above. The perceived risk of apprehension could increase among motivated offenders when they notice potential targets are carrying a mobile phone. As technology has improved to allow the transmission of photographic images, identification, apprehension, prosecution, and conviction all presumably become even more likely. Such technology lowers the cost victims bear in reporting crime; ${ }^{2}$ it also allows bystanders to provide details of crimes at a very low cost. ${ }^{3}$ In

\footnotetext{
${ }^{2}$ See, for example, http://www.nytimes.com/2008/09/19/nyregion/19arrest.html

${ }^{3}$ See, for example the Swift Report Network, http://www.swiftreport.net/, which provides a central forum for such reports.
} 
some instances, a victim's phone may inadvertently provide clues that help identify a criminal. Similarly, for some crimes, the perpetrator's mobile phone can provide evidence as well. ${ }^{4}$

While this effect of mobile phones would appear to unambiguously lead to a decline in violent crime in the Becker framework, things are not as clear with respect to property crime. First, mobile phones are an attractive target for thieves. At least initially, the phones themselves were high value items that could be sold easily. Their small size also makes them relatively attractive targets. Roman and Chaflin (2008) note there was a significant and short-lived uptick in reported robberies in 2005 and 2006 following the mass introduction of iPod portable media devices. Further, the phones can be used cost free for a period of time until the victim cancels the service. Popular accounts of cell phone theft suggest that it has been a large problem ever since the technology became popular. ${ }^{5}$ Mobile phones, especially prepaid unregistered ones, might also be helpful in the activities of gangs and other crime organizations. ${ }^{6}$

\section{Empirical Analysis}

Unfortunately, it is not possible to directly analyze the contribution of mobile phones to the 1990s crime decline. Comprehensive data below the national level are not available before 1999. Data after this period come from information filed by mobile phone service providers with the FCC. $^{7}$ Service providers must make these filings by March 1 and September 1 of each year. ${ }^{8}$

Another problem that hampers strong causal inferences with respect to the effect of mobile phones on crime is the lack of a strong instrument or natural experiment to isolate the true causal effect of mobile phones on crime. There are a number of reasons one may be suspicious of regression results in the absence of such clearly random variation. For example, a reverse causality problem might exist whereby individuals fearing crime may purchase phones for their protection. This particular omitted variable bias may not be particularly troubling, at least in terms of verifying a link between mobile phones and crime, since, at least in a bivariate regression framework, it would imply that any estimated deterrence relationship is under-stated. Further, this mechanism in itself would provide some supporting evidence at least regarding people's belief that mobile phones are useful for counteracting criminals.

\footnotetext{
${ }^{4}$ An obvious instance of this is to provide location information for tracking or verification purposes. In some cases, the evidence is even more direct. See, for example, http://www.theolympian.com/2010/06/26/1285839/video-ondonated-cell-phone-leads.html .

${ }^{5}$ See, for example, http://www.time.com/time/magazine/article/0,9171,214207,00.html .

6 This concern is vividly portrayed in the HBO series "The Wire"

(http://www.youtube.com/watch?v=PojAnXG9wwU ). A number of politicians in the US and abroad have considered banning unregistered prepaid mobile phones on these grounds. See, for example, http://schumer.senate.gov/record.cfm?id=325263 .

${ }^{7}$ See "Local Telephone Competition” section of http://www.fcc.gov/wcb/iatd/comp.html .

${ }^{8}$ http://www.fcc.gov/form477/
} 
More problematic biases might arise if there are income or wealth effects that lead to increasing mobile phone penetration rates and declining crime rates. To mitigate this source of bias, we control for real state (per capita) income below, but clearly this approach cannot rule out the possibility of bias.

Our analysis covers the period 1999-2007 at the state level. Our primary outcomes of interest are rape and aggravated assault rates recorded as part of the FBI's Uniform Crime Reports (UCR). We rely on these crime outcomes because they are likely to occur among strangers and most plausibly deterred by mobile phones. Assaults among intimates or acquaintances are more likely to be reported as misdemeanor simple assaults. Sexual assaults among non-strangers are also less likely to be classified as rapes by the police. The FBI's UCR defines rape as “The carnal knowledge of a female forcibly and against her will.” The FBI also provides law enforcement agencies with scenarios that clearly show the focus is on sexual assaults committed by strangers (Uniform Crime Reporting Handbook, 2004; p. 19).

1. Law enforcement received a complaint from a victim who claimed that when she was leaving work late one night, she was attacked in the company parking lot by an unidentified male and forcibly raped. The offender was not apprehended.

2. Two men lured a woman to their motel room with the promise of discussing a job opportunity. They threatened her with a knife and both forcibly raped her. On complaint by the woman, the police arrested both men.

3. Three girls were attacked, assaulted, and raped by four boys. Each boy raped each of the girls. No arrests were made.

Some policy makers have noted the potential mobile phones have for providing evidence in rape investigations. ${ }^{9}$ Particularly as more phones include cameras, the evidentiary possibilities grow substantially, providing better descriptions in the case of stranger rapes and possibly adding veracity to claims in "he said/she said" scenarios in acquaintance rapes. Further, a victim in these cases might be able to discourage the sexual assault simply by brandishing the phone and threatening to report. To the extent the attacker is cognizant of any of these effects, rape rates should decline on the margin. Similar arguments apply in the case of assault and perhaps even homicide, though in the case of the latter, homicide was quite rare in this time period (averaging just 5.6 per 100,000 population in the period 1999-2007), most of the substantial drop in homicide occurred in the 1990s, and it has since exhibited very little variation as shown in Figure 2.

\footnotetext{
${ }^{9}$ See, for example, http://www.heraldscotland.com/mobile/0news/crime-courts/new-ways-to-help-rape-victims1.1058614
} 


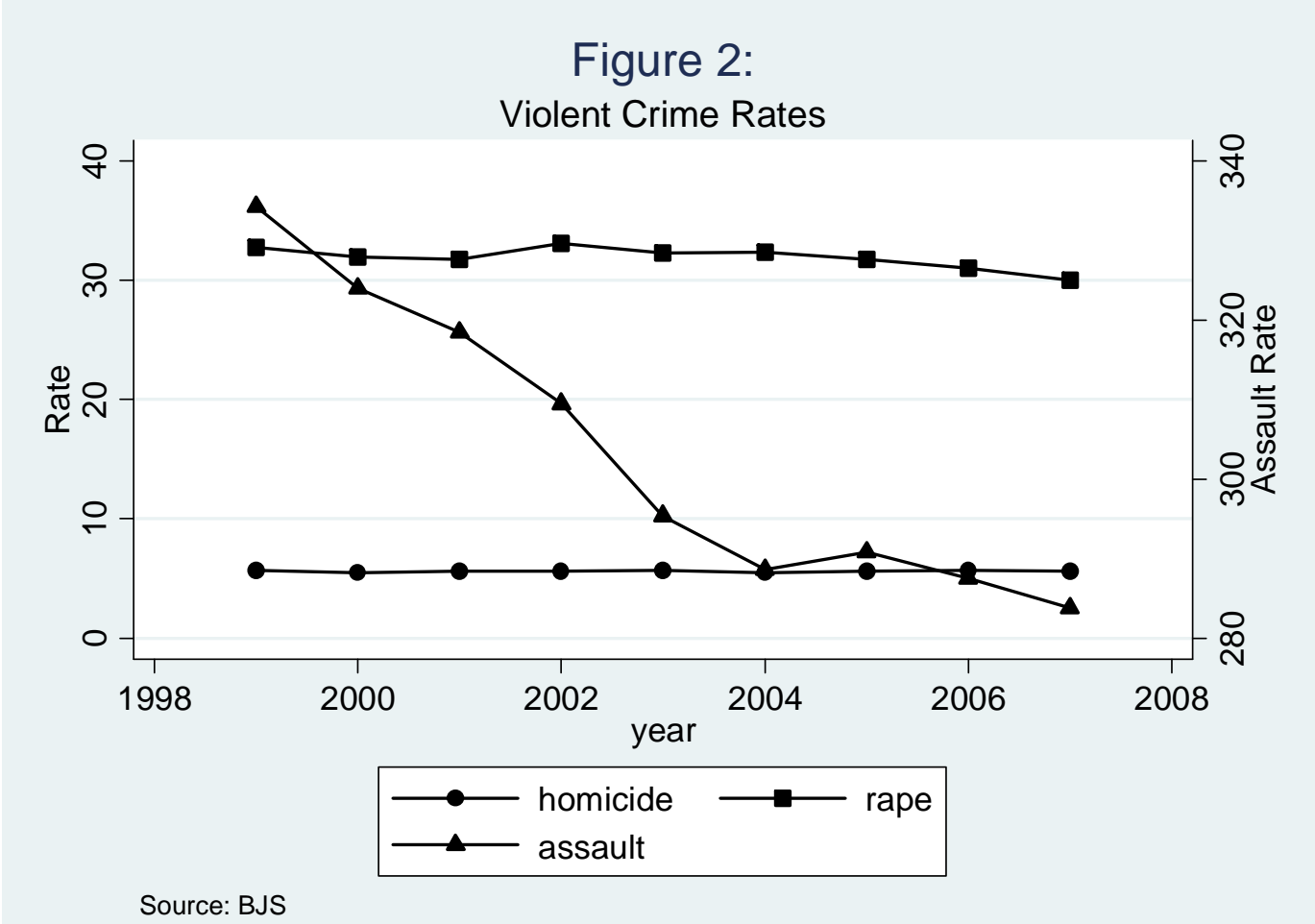

For controls, we include real per capita GDP, as well as per capita spending on corrections and police to account for changes in other policies that may affect deterrence. ${ }^{10}$ The state GDP control should account for some of the increase in mobile phone penetration that is explained by wealth or income effects, though this control is not perfect. In some subsequent regressions, we allow the relationship between crime and income to vary state to state as a robustness test.

For our primary measure of mobile phone penetration, we use the total number of mobile phone subscriptions in a state in a given year. An alternative would be to use this number as a fraction of total state population. We prefer the former since a number of state year cells exhibit more mobile phone subscriptions than people residing in the state. ${ }^{11}$ Presumably, individuals with more than one subscription are much more likely to actually have a mobile phone in their possession at any given time. States with a large number of such people may project the appearance that mobile phones are ubiquitous, heightening any deterrence effect. Summary statistics are presented in Table 1.

\section{Table 1: Summary Statistics}

\footnotetext{
${ }^{10}$ The spending variables are linearly extrapolated based on real per capita state GDP for the years 2006 and 2007 since BJS has not yet released data for these years. Real per capita GDP was used as the pattern series rather than a simple time trend since the GDP variable explains much more variation in these spending variables than does a time trend. This is true even if level differences across states are removed from the data.

${ }^{11}$ Results are comparable if we normalize subscriptions by population.
} 


\begin{tabular}{|l|l|l|l|l|}
\hline \multicolumn{1}{|c|}{ Variable } & \multicolumn{1}{|c|}{ Description } & \multicolumn{1}{|c|}{ Sean } & \multicolumn{1}{c|}{ Source } \\
\hline Mobile Phones & $\begin{array}{l}\text { Number of mobile phone subscriptions } \\
\text { in 1000s }\end{array}$ & 7,328 & 6,923 & FCC \\
\hline $\begin{array}{l}\text { Mobile Phone } \\
\text { Rate }\end{array}$ & $\begin{array}{l}\text { Number of mobile phones divided by } \\
\text { state population }\end{array}$ & 0.56 & 0.18 & FCC \\
\hline Violent Crime & $\begin{array}{l}\text { Number of violent crimes per 100,000 } \\
\text { state residents }\end{array}$ & 486 & 160 & BJS \\
\hline Rape & $\begin{array}{l}\text { Number of rapes per 100,000 state } \\
\text { residents }\end{array}$ & 32 & 9 & BJS \\
\hline Assault & $\begin{array}{l}\text { Number of assaults per 100,000 state } \\
\text { residents }\end{array}$ & 303 & 120 & BJS \\
\hline Property Crime & $\begin{array}{l}\text { Number of property crimes per 100,000 } \\
\text { state residents }\end{array}$ & 3,529 & 810 & BJS \\
\hline GDP & $\begin{array}{l}\text { Real per capita domestic product in a } \\
\text { state (2005 dollars) }\end{array}$ & 41,157 & 7,051 & BEA \\
\hline Police & $\begin{array}{l}\text { Per capita spending on police (state and } \\
\text { local) in a state }\end{array}$ & 231 & 84 & BJS \\
\hline $\begin{array}{l}\text { Corrections } \\
\text { state capita spending on corrections in }\end{array}$ & 189 & 55 & BJS \\
\hline $\begin{array}{l}\text { Note: Means and standard deviations are weighted by population. Data cover 1999-2007. } \\
\text { Police and corrections are linearly extrapolated on the basis of real per capita GDP for the years } \\
\text { 2006 and 2007. Data sources are the Federal Communications Commission (FCC), the Bureau } \\
\text { of Justice Statistics (BJS), and the Bureau of Economic Analysis (BEA). }\end{array}$ \\
\hline
\end{tabular}

Additionally, we include state and year fixed effects to account for constant idiosyncratic differences across states as well as common non-linear time trends. Because our dependent variables are rates, we use population weights in the primary regressions. Angrist and Pischke (2008) suggest that the standard approach of using weighted least squares is unwarranted on the usual justification of heteroskedasticity grounds, given that heteroskedasticity robust standard errors are easily calculated. They also warn that weighted least squares can lead to biased coefficients. We suggest, however, that the most interesting phenomena studied by social scientists exhibit treatment effect heterogeneity. If regressions are not weighted in a context like the current one, mean effects will weight what happens in Rhode Island equally with what happens in California. Such an approach is problematic. However, we do present results with equal weighting as well to demonstrate that our primary estimates are not driven by this kind of "bias."

We use standard errors that are robust to clustering both at the state and year level as discussed in Cameron, Gelbach, and Miller (2010). Clustering at the state level is used to account for the kind of serial dependence discussed in Bertrand, Duflo, and Mullainathan (2004). Clustering at the year level is used to account for measurement error related to changes in the reporting 
behavior of the mobile phone providers, as well as dependence arising from common technology shocks affecting the national market for mobile phones.

In Table 2, we present the results for the rates of violent crime in total, rape, assault, and total property crimes with state and year fixed effects but no control variables.

\begin{tabular}{|l|l|l|l|l|}
\hline \multicolumn{5}{|c|}{ Table 2: } \\
\hline \multicolumn{5}{|c|}{ The Relationship Between Mobile Phones and Crime Rates } \\
\hline \multicolumn{5}{|c|}{ (Standard Errors Clustered Separately on State and Year in Parentheses) } \\
\hline & \multicolumn{1}{|c|}{ Violent Crime } & \multicolumn{1}{|c|}{ Assault } & Property Crime \\
\hline Mobile Phones & $-0.005^{* * *}$ & $-0.0002^{* * *}$ & $-0.005^{* * *}$ & 0.01 \\
& $(0.001)$ & $(0.0001)$ & $(0.001)$ & $(0.01)$ \\
\hline State Effects & Yes & Yes & Yes & Yes \\
\hline Year Effects & Yes & Yes & Yes & Yes \\
\hline Weighting & Population & Population & Population & Population \\
\hline $\begin{array}{l}* * * p<0.01 \text { (against a two-sided test of a 0 effect) } \\
* * p<0.05 \text { (against a two-sided test of a 0 effect) } \\
* \mathrm{p}<0.10 \text { (against a two-sided test of a 0 effect) }\end{array}$ \\
\hline
\end{tabular}

As suggested, all of the violent crime measures exhibit a negative relationship with the number of mobile phones in a state, whereas the property crime rate does not. The magnitude of the effect is generally large as well. In the sample, the average increase in mobile phone subscriptions in a given year is about 1,000,000 which translates into 5 fewer violent crimes per 100,000 people (a relative effect of about 1 percent), 2 fewer rapes per 1,000,000 people (an effect greater than 0.5 percent), and 5 fewer assaults per 100,000 people (an effect greater than 1.5 percent). An increase of a standard deviation in mobile phone subscriptions would imply effects 7 times as large.

As suggested above, however, it would be reasonable to look at mobile phone subscriptions normalized by population. We provide the same analysis using this metric in Table 3.

\begin{tabular}{|c|c|c|c|c|}
\hline \multicolumn{5}{|c|}{ Table 3: } \\
\hline \multicolumn{5}{|c|}{ The Relationship Between Mobile Phones and Crime Rates } \\
\hline \multicolumn{5}{|c|}{ (Standard Errors Clustered Separately on State and Year in Parentheses) } \\
\hline & Violent Crime & Rape & Assault & Property Crime \\
\hline $\begin{array}{l}\text { Mobile Phone } \\
\text { Rate }\end{array}$ & $\begin{array}{l}-212 * * \\
(90)\end{array}$ & $\begin{array}{l}-7 \\
(5)\end{array}$ & $\begin{array}{l}-169 * \\
(87)\end{array}$ & $\begin{array}{l}-42 \\
(612)\end{array}$ \\
\hline State Effects & Yes & Yes & Yes & Yes \\
\hline Year Effects & Yes & Yes & Yes & Yes \\
\hline Weighting & Population & Population & Population & Population \\
\hline $\begin{array}{l}* * * \mathrm{p}<0.01(\mathrm{a} \\
*^{* *} \mathrm{p}<0.05(\mathrm{ag} \\
{ }^{*} \mathrm{p}<0.10 \text { (aga }\end{array}$ & $\begin{array}{l}\text { st a two-sided tes } \\
\text { a two-sided test } \\
\text { two-sided test o }\end{array}$ & $\begin{array}{l}\text { f a } 0 \text { effect) } \\
\text { a } 0 \text { effect) } \\
0 \text { effect) }\end{array}$ & & \\
\hline
\end{tabular}


While the results are clearly less precisely estimated, the implied effects are even larger than those presented in Table 2 if we use the average increase in mobile phones (normalized by population) in a given year or a one standard deviation increase as the point of evaluation. This suggests that our effect is not merely an artifact of peculiar effects observed in large states.

Table 4 provides the analysis where states are weighted equally.

\begin{tabular}{|l|l|l|l|l|}
\hline \multicolumn{5}{|c|}{ Table 4: } \\
\hline \multicolumn{5}{|c|}{ The Relationship Between Mobile Phones and Crime Rates } \\
\hline \multicolumn{5}{|c|}{ (Standard Errors Clustered Separately on State and Year in Parentheses) } \\
\hline & \multicolumn{1}{|c|}{ Violent Crime } & \multicolumn{1}{|c|}{ Assault } & Property Crime \\
\hline Mobile Phones & $-0.006^{* * *}$ & -0.0002 & $-0.005^{* * *}$ & 0.005 \\
& $(0.002)$ & $(0.0002)$ & $(0.001)$ & $(0.014)$ \\
\hline State Effects & Yes & Yes & Yes & Yes \\
\hline Year Effects & Yes & Yes & Yes & Yes \\
\hline Weighting & Equal & Equal & Equal & \\
\hline$* * * p<0.01$ (against a two-sided test of a 0 effect) & & \\
$*_{* *} \mathrm{p}<0.05$ (against a two-sided test of a 0 effect) \\
$* \mathrm{p}<0.10$ (against a two-sided test of a 0 effect) \\
\hline
\end{tabular}

While the precision of the rape estimate drops considerably, none of the point estimates suggest that weighting can be generating any bias, the concern of Angrist and Pischke. In fact, the violent crime estimate appears to grow slightly in magnitude. Given our preference to use total mobile phone subscriptions and weighted least squares, combined with the evidence that these choices are not driving any of our estimates, we proceed with these choices in the tables that follow.

Table 5 includes our control variables described above.

\begin{tabular}{|l|l|l|l|l|}
\hline \multicolumn{5}{|c|}{ Table 5: } \\
\hline \multicolumn{5}{|c|}{ The Relationship Between Mobile Phones and Crime Rates } \\
\hline \multicolumn{4}{|c|}{ (Standard Errors Clustered Separately on State and Year in Parentheses) } \\
\hline \multirow{2}{*}{ Mobile Phones } & $-0.004^{* * *}$ & $-0.0002^{* *}$ & $-0.005^{* * *}$ & $0.02^{*}$ \\
& $(0.001)$ & $(0.0001)$ & $(0.001)$ & $(0.01)$ \\
\hline GDP & $-0.006^{* * *}$ & -0.0002 & $-0.003^{* *}$ & $-0.04^{* * *}$ \\
& $(0.002)$ & $(0.0002)$ & $(0.001)$ & $(0.01)$ \\
\hline Police & -0.06 & 0.001 & -0.04 & -0.56 \\
& $(0.03)$ & $(0.004)$ & $(0.02)$ & $(0.42)$ \\
\hline Corrections & 0.08 & -0.001 & 0.06 & -0.55 \\
& $(0.09)$ & $(0.006)$ & $(0.06)$ & $(0.62)$ \\
\hline State Effects & Yes & Yes & Yes & Yes \\
\hline
\end{tabular}




\begin{tabular}{|l|l|l|l|l|}
\hline Year Effects & Yes & Yes & Yes & Yes \\
\hline Weighting & Population & Population & Population & Population \\
\hline$* * * p<0.01$ (against a two-sided test of a 0 effect) & \\
${ }^{* *} \mathrm{p}<0.05$ (against a two-sided test of a 0 effect) & \\
${ }^{*} \mathrm{p}<0.10$ (against a two-sided test of a 0 effect) & \\
\hline
\end{tabular}

Adding the covariates does very little to change our point estimates. In all four crime measures, the estimated effect of mobile phone subscriptions is stable relative to the specification that does not include the covariates. This is surprising given the hypothesized relationships between income and both crime and mobile phone penetration. Perhaps this provides some confidence that the estimated effect is not primarily driven by omitted variables bias. However, without better identification strategies, we must take these results as being merely suggestive of a deterrent effect of mobile phones on violent crime.

As one last robustness test, we allow the income effect to differ by state. We present these results in Table 6, suppressing the covariate estimates for presentation purposes.

\begin{tabular}{|c|c|c|c|c|}
\hline \multicolumn{5}{|c|}{ Table 6: } \\
\hline \multicolumn{5}{|c|}{ The Relationship Between Mobile Phones and Crime Rates } \\
\hline \multicolumn{5}{|c|}{ (Standard Errors Clustered Separately on State and Year in Parentheses) } \\
\hline & Violent Crime & Rape & Assault & Property Crime \\
\hline Mobile Phones & $\begin{array}{l}-0.003 \\
(0.003)\end{array}$ & $\begin{array}{l}-0.0001^{* *} \\
(0.0002)\end{array}$ & $\begin{array}{l}-0.004^{*} \\
(0.002)\end{array}$ & $\begin{array}{l}0.01 \\
(0.03)\end{array}$ \\
\hline State Effects & Yes & Yes & Yes & Yes \\
\hline Year Effects & Yes & Yes & Yes & Yes \\
\hline Weighting & Population & Population & Population & Population \\
\hline \multicolumn{5}{|c|}{$\begin{array}{l}\text { Note: all regressions include GDP, Police, and Corrections as covariates. } \\
*_{* *} p<0.01 \text { (against a two-sided test of a } 0 \text { effect) } \\
*^{* *}<0.05 \text { (against a two-sided test of a } 0 \text { effect) } \\
{ }^{*} p<0.10 \text { (against a two-sided test of a } 0 \text { effect) }\end{array}$} \\
\hline
\end{tabular}

This specification generates more variability in the estimates, lowering confidence in the original analysis. Though, here too, important effects of mobile phones on crime are implied, even if only the mobile phone coefficient in the assault equation remains statistically significant at the 10 percent level. $^{12}$

Another source of concern is the presence of a number of potential outliers in the sample. For example, the District of Columbia has an average violent crime rate that is almost four times the sample mean, while its mean subscriber figure normalized for population exceeds one. To

\footnotetext{
${ }^{12}$ Although, it is interesting to note that if we run this regression with equal weighting, the coefficient in the violent crime equation is statistically significant at the 10 percent level and the coefficient in the assault equation is statistically significant at the 5 percent level.
} 
examine the influence of extreme value observations in the dataset, we present the results of a leverage robust regression technique in Table $7 .^{13}$

\begin{tabular}{|c|c|c|c|c|}
\hline \multicolumn{5}{|c|}{ Table 7: } \\
\hline \multicolumn{5}{|c|}{ The Relationship Between Mobile Phones and Crime Rates } \\
\hline \multicolumn{5}{|c|}{ Robust Regression Results } \\
\hline & Violent Crime & Rape & Assault & Property Crime \\
\hline Mobile Phones & $\begin{array}{l}-0.005 * * * \\
(0.001)\end{array}$ & $\begin{array}{l}-0.0003^{* * * *} \\
(0.0001)\end{array}$ & $\begin{array}{l}-0.005^{* * *} \\
(0.001)\end{array}$ & $\begin{array}{l}0.01^{*} \\
(0.01)\end{array}$ \\
\hline State Effects & Yes & Yes & Yes & Yes \\
\hline Year Effects & Yes & Yes & Yes & Yes \\
\hline \multicolumn{5}{|c|}{$\begin{array}{l}\text { Note: all regressions include GDP, Police, and Corrections as covariates. } \\
*_{* *} \mathrm{p}<0.01 \text { (against a two-sided test of a } 0 \text { effect) } \\
*^{* *} p<0.05 \text { (against a two-sided test of a } 0 \text { effect) } \\
{ }_{p} p<0.10 \text { (against a two-sided test of a } 0 \text { effect) }\end{array}$} \\
\hline
\end{tabular}

The results from the leverage robust regression estimation suggest that the results are not driven by high leverage observations. Each coefficient is as large in magnitude, and larger in the cases of violent crime and rape, in the robust regression specification as it is in the corresponding regression from Table 5.

One last robustness check we perform is to allow for region specific nonlinear time trends (i.e., year dummies that vary by region of the U.S.) to account for possible differences in the diffusion of mobile phones and coincident changes in crime patterns. We present these results in Table 8.

\begin{tabular}{|c|c|c|c|c|}
\hline \multicolumn{5}{|c|}{ Table 8: } \\
\hline \multicolumn{5}{|c|}{ The Relationship Between Mobile Phones and Crime Rates } \\
\hline \multicolumn{5}{|c|}{ (Standard Errors Clustered Separately on State and Year in Parentheses) } \\
\hline & Violent Crime & $\begin{array}{r}\text { Rape } \\
\end{array}$ & Assault & Property Crime \\
\hline Mobile Phones & $\begin{array}{l}-0.005 * * * \\
(0.001)\end{array}$ & $\begin{array}{l}-0.0002 * * \\
(0.0001)\end{array}$ & $\begin{array}{l}-0.005^{* * *} \\
(0.001)\end{array}$ & $\begin{array}{l}0.01 \\
(0.01) \\
\end{array}$ \\
\hline State Effects & Yes & Yes & Yes & Yes \\
\hline $\begin{array}{l}\text { Region X Year } \\
\text { Effects }\end{array}$ & Yes & Yes & Yes & Yes \\
\hline Weighting & Population & Population & Population & Population \\
\hline \multicolumn{5}{|c|}{$\begin{array}{l}\text { Note: all regressions include GDP, Police, and Corrections as covariates. } \\
* * * \mathrm{p}<0.01 \text { (against a two-sided test of a } 0 \text { effect) } \\
* * \mathrm{p}<0.05 \text { (against a two-sided test of a } 0 \text { effect) } \\
{ }_{\mathrm{p}}<<0.10 \text { (against a two-sided test of a } 0 \text { effect) }\end{array}$} \\
\hline
\end{tabular}

\footnotetext{
${ }^{13}$ Specifically, we use the rreg command in Stata. Note that this command does not allow for clustering of standard errors and it weights inversely according to an observation's leverage as opposed to the population weighting used above.
} 
Allowing for more generality in the time effects does not affect our estimates of the effect of mobile phones on crime.

While we do not have a strong identification strategy, beyond using state and year fixed effects, our estimates exhibit a surprising degree of robustness. While it is not possible to state with confidence that there is a strongly negative effect of mobile phone penetration on violent crime rates, much less make a claim that this effect played an important role in the crime decline observed in the 1990s, the results are interesting and deserve further exploration if additional data or a better design becomes available. This effect may help to explain the puzzle of why crime rates did not begin to decline earlier since the mobile phone effect is one that is specific to the mid-1990s and beyond. Given the plausibility of the hypothesis and the robustness of our results, it is worthwhile exploring the policy implications of any mobile phone effect.

\section{Policy Implications}

Criminal justice policy is typically focused on the supply of public expenditures to deter offending, incapacitate active offenders, or promote rehabilitation. The primary focus in the U.S. has been on deterrence and incapacitation. Increased police strength (Evans and Owens 2007) and more efficiently allocating police to problematic places or crime hot spots (Weisburd and Eck 2004) are among the more promising areas of criminal justice policy with some evidence of deterrence payoffs. Prison expansion has been credited for some measurable crime reduction through incapacitation, but there are numerous negative externalities of prison including its effect on future labor market prospects and the direct public costs (over \$20 billion a year) of detaining individuals for long periods of time in secure institutions (Spelman 2006). The focus on crime policy has underplayed the role of private efforts to prevent crime and the role that individuals play in their own risk of victimization.

The descriptive analysis of the state by year adoption of mobile phones suggests that this technology may coincide with other increases in private crime prevention that helped facilitate the crime drop of the 1990s. Our findings at least suggest some effect of mobile phones on sustaining the historically low rates of crimes of interpersonal violence between 1999 and 2007 in states.

Mobile phones provide the average citizen with the ability to effortlessly contact the police and provide exact coordinates for a crime, perhaps increasing the provision of timely reports of criminal activity to the police. The near-universal adoption of mobile phones makes these devices less likely to produce negative externalities noted in other investments in private security, like burglar alarms and security fences, that displace crime to other targets. The use of mobile phones to deter crime is also consistent with a Becker model and a routine activities theory of crime. Mobile phones increase surveillance. When motivated offenders converge in 
time and place with suitable targets the average level of guardianship of those targets increases with the presence of a mobile phone. This is particularly true in the case of assaults and rapes committed by strangers, where a potential victim is no longer completely isolated and can contact the police for assistance. An increased level of guardianship of potential victims raises the costs of crimes to motivated offenders. An added benefit of mobile phones is that their deterrent benefit doesn't require additional supply of public expenditures to criminal justice programs.

\section{Conclusion}

This is the first study to posit that the introduction and adoption of cell phones led to a decrease in crime. We develop a model of this mechanism and use our framework to generate testable hypotheses. We hypothesize that cell phones had the largest negative impact for violent crimes and a lesser impact for property crimes. We test our theory using recent data and find support for our hypotheses. Our conclusions are unchanged after conducting a number of robustness tests.

Although our regressions control for state specific and year specific characteristics, and a number of other control variables, the estimates need to be interpreted with caution. In particular, if we omitted variables that are correlated with cell phone adoption rates as well as with crime, our estimates are biased.

Nonetheless, our results are consistent with our model, suggesting that cell phone adoption lowers crime. This implies that there may be relatively cheap alternatives to putting cops on the street in order to fight crime. In particular, our findings points to private solutions to deter crime. However, for the U.S., many of the gains from cell phone use may have already been realized, given that a large fraction of the population already uses cell phones. However, by encouraging individuals to take cell phones with them when leaving their residences, cell phones have the potential to further reduce crime.

Future work may consider a different identification strategy to isolate the causal effect of cell phones, and determine by which mechanism cell phones lower crimes. For example, are criminals deterred by the mere possibility that potential victims will use their cell phone, are they deterred when they observe potential victims using their mobile device, or are they deterred because individuals will pull out their cell phone when they consider themselves close to an encounter with a criminal? Answers to these questions will further illuminate how cell phone adoption reduces crime. 


\section{References}

Angrist, Josh, and Jorn-Steffen Pischke (2007). Mostly Harmless Econometrics: An Empiricist's Companion, Princeton University Press.

Ayres, Ian, and Steven Levitt (1998). "Measuring Positive Externalities from Unobservable Victim Precaution: An Empirical Analysis of Lojack.” Quarterly Journal of Economics, 113(1): 43-77.

Becker, Gary S. 1968. "Crime and Punishment: An Economic Approach," Journal of Political Economy 76, 2: 169-217.

Blumstein, Alfred. 2000. "Disaggregating the Violence Trends." In The Crime Drop in America, edited by Alfred Blumstein and Joel Wallman. New York: Cambridge University Press: 13-44.

Blumstein, Alfred, and Joel Wallman. 2000. The Crime Drop in America. New York: Cambridge University Press.

Brooks, Leah 2008. "Volunteering to Be Taxed: Business Improvement Districts and the ExtraGovernmental Provision of Public Safety” Journal of Public Economics 92, 388-406.

Cohen, Lawrence, and Marcus Felson. 1979. "Social Change and Crime Rate Trends: A Routine Activity Approach,” American Sociological Review, 44, 588-608

Cook, Philip J. 1986. “The demand and supply of criminal opportunities,” Crime and Justice VII: 1-27.

Cook, Philip J., and John H. Laub. 2002. "After the Epidemic: Recent Trends in Youth Violence in the United States." In Crime and Justice: A Review of Research, edited by Michael Tonry. Chicago: University of Chicago Press: 117-153.

Cook, Philip J., and John M. MacDonald. 2011a. "Public Safety through Private Action: An Economic Assessment of BIDs.” The Economic Journal (forthcoming).

Cook, Philip J., and John M. MacDonald. 2011b. “Limiting Criminal Opportunities.” In Controlling Crime: Strategies and Tradeoffs (Eds. P. Cook, J. Ludwig, \& J. McCrary). Chicago: University of Chicago Press (forthcoming).

Donohue, John, and Steven Levitt (2001). “The Impact of Legalizaed Abortion on Crime.” Quarterly Journal of Economics, 116(2): 379-420. 
Evans, W. N. and Owens, E. G. (2007). "COPS and Crime" Journal of Public Economics 91(2): 181-201.

Levitt, Steven (2004). "Understanding Why Crime Fell in the 1990s: Four Factors that Explain the Decline and Six That Do Not.” Journal of Economic Perspectives, 18: 163-190.

Reyes, Jessic (2007). "Environmental Policy as Social Policy? The Impact of Childhood Lead Exposure on Crime.” B.E. Journal of Economic Analysis and Policy, 7:1.

Roman, J. and A. Chalfin. 2008. "Has demand for crime increased: Does the increase in the prevalence of personal media devices explain the violent crime spike in 2005 and 2006?" American Criminal Law Review. 45(3), 1149-1166.

Spelman, William. 2006. The limited importance of prison expansion. In The Crime Drop in America (Eds. A. Blumstein \& J. Wallman). New York: Cambridge University Press.

Weiner, David, Byron Lutz and Jens Ludwig. "The Effects of School Desegregation on Crime.” Working Paper, University of Chicago.

Weisburd, David, \& John E. Eck (2004) “'What Can Police Do to Reduce Crime, Disorder, and Fear?,"' The Annals of the American Academy of Political and Social Science, 593, 42-65. 